\title{
TOKOH FALAK MINANGKABAU (STUDI PEMIKIRAN SAADOEDDIN DJAMBEK DAN TAHIR JALALUDDIN)
}

\author{
Hendri \\ IAIN Bukittinggi, hendridatuak7@gmail.com \\ Fajrul Wadi \\ LAIN Bukittinggi,fajrulwadi74@gmail.com \\ Saiful Amin \\ IAINBukittinggi,saifulamin@gmail.com \\ Andriyaldi \\ IAIN Bukittinggi, akhi_andriyaldi@gmail.com \\ Fahmil Samiran \\ LAIN Bukittinggi,fahmilsamiran@iainbukittinggi.ac.id
}

\begin{tabular}{l|l|l} 
Diterima: 5 Januari 2019 & Direvisi:12 Maret 2019 & Diterbitkan: 30 Juni 2019
\end{tabular}

\begin{abstract}
This paper talks about the contribution of the Minangkabau Falak figures about dawn in Indonesia. At this time of dawn in Indonesia which is used as a reference or guideline of the Ministry of Religion that is the result of the thoughts and ijtihad of the previous scholars who are still in use today for the height and position of the sun at the time of the dawn of Sadiq -200. The clerics and celestial figures who be ijtihad about dawn with the -200 position came from Minangkabau namely Saadoeddin Djambek which is famous for the books of prayer and fasting in the polar regions. Saadoeddin djambek set -200 by quoting the opinion of his teacher, Sheikh Muhammad Tahir Jalaluddin al-Minangkabawi about determining the prayer time in Pati Kiraan and Nukhbah at-Taqrîrât fîHisâb al-Auqât was Samt al-Qiblah bi al-Lughâritmât. Determination of the height of the sun at the -200 position is based on geographical observations and considerations due to the factor of Indonesia that is close to the equator and influenced by astronomical data used, solar height and its correction as well as the determination of latitude and longitude.
\end{abstract}

Keywords: Falak, Minangkabau

\begin{abstract}
Abstrak
Tulisan ini berbicara tentang kontribusi Tokoh Falak Minangkabau tentang waktu subuh di Indonesia. Pada saat ini waktu subuh di Indonesia yang dijadikan acuan atau pedoman Kementrian Agama yaitu hasil pemikiran dan ijtihad para ulama terdahulu yang masih di pakai saat ini untuk ketinggian serta posisi matahari pada waktu kemunculan fajar shadiq 20․ Adapun ulama dan tokoh Falak yang berijtihad mengenai waktu subuh dengan posisi $20^{\circ}$ itu berasal dari Minangkabau yaitu Saadoeddin Djambek yang terkenal dengan buku salat dan puasa di daerah kutub. Saadoeddin djambek menetapkan $-20^{\circ}$ dengan mengutip pendapat gurunya yaitu Syeikh Muhammad Tahir Jalaluddin al-Minangkabawi pada kitab pati kiraan dan kitab Nukhbah at-Taqrîrât fî Hisâb al-Auqât wa Samt al-Qiblah bi al-Lughâritmât. Penetepan ketinggiann matahari pada posisi $-20^{\circ}$ ini berdasarkan hasil pengamatan geografis dan pertimbangan dikarenakan faktor Indonesia yang dekat dengan equator serta di pengaruhi oleh data data astronomi yang dipakai, tinggi matahari dan koreksiannya serta penentuan lintang dan bujur tempat.
\end{abstract}

Kata Kunci: Falak. Minangkabau 


\section{PENDAHULUAN}

Ilmu Falak atau Ilmu Hisab merupakan salah satu ilmu keislaman yang terlupakan. Padahal ilmu ini telah dikembangkan oleh ilmuwan-ilmuwan muslim sejak abad pertama Hijriyah yang bukan hanya pengembangan ilmu itu sendiri, tetapi untuk kepentingan praktis dalam menjalankan Rukun Islam. Rukun Islam ada lima, yaitu 1) mengucapkan dua kalimat Syahadat, 2) mengerjakan Shalat Fardhu 5 waktu sehari semalam, 3) berpuasa dalam bulan Ramadhan, 4) mengeluarkan Zakat Fithrah, 5) menunaikan ibadah Haji bagi yang mampu. ${ }^{1}$ Ilmu Falak di Indonesia, sering menjadi acuan dalam menentukan waktu awal dan akhir Puasa Ramadhan dan juga hari raya Idul Adha. ${ }^{2}$

Dalam khasanah intelektual muslim Ilmu Falak merupakan ciri dari kemajuan peradaban Islam. Namun dalam perjalannya Ilmu Falak hanya mengkaji persoalan persoalan ibadah. Seiring perkembangan zaman Ilmu Falak berkembang pesat tak terkecuali di Indonesia. Pada awalnya masyarakat Indonesia sudah mengenal Ilmu Falak. Ini di tandai dengan sudah adanya penanggalan Hindu dan penanggalan Islam khususnya di pulau jawa serta adanya perpaduan kedua penganggalan tersebut menjadi penanggalan jawa Islam oleh Sultan Agung. ${ }^{3}$

Khusus di Sumatera, sebagian masyarakat pun sudah mengenal Ilmu Falak. Ini dapat di lihat dari adanya tokoh Falak yang antara lain Thahir Djaluddin dan Saadoeddin

1 Reza Akbar, "Sejarah Perkembangan Ilmu Falak Dalam Peradaban India Dan Keterkaitannya Dengan Islam," Jurnal Ilmiah Islam Futura 17 (2017): 5072.

2 Muhamad Rezi, "Pemahaman Hadis-Hadis Rukyat Hilal Dan Relasinya Dengan Realita Isbât Ramadhan Di Indonesia," Alburriyah: Jurnal Hukum Islam 1, no. 1 (June 10, 2016): 109-24, https://doi.org/10.30983/ALHURRIYAH.V1I1.484.

${ }^{3}$ Reza Akbar, Sejarah ...., 73.
Djambek. Kedua tokoh inipun melahirkan karyanya.

\section{METODE PENULISAN}

Tulisan ini mengkaji mengenai pemikiran Tokoh Falak asal Minangkabau terkait waktu sholat yaitu ketinggian matahari pada waktu subuh serta kontribusinya di Indonesia. penelitian akan mengemukakan terkait dengan biografi Tokoh Falak Minangkabau dimulai dengan biografi, pendidikan serta corak pemikirannya dalam Ilmu Falak khususnya terkait dengan ketinggian matahari pada waktu subuh.

Selanjutnya penulis menggunakan metode deksriptif analitik dan content analysis untuk menganalisis pemikiran tokoh Falak Minangkabau yaitu Saadoedin Djambek dan Syeikh Tahir Jalaluddin yang menjadikan karya pemikiran tokoh Falak Minangkabau sebagai sumber primer.

\section{BIOGRAFI SAADOEDDIN DJAMBEK}

Saadoe'ddin Djambek merupakan salah seorang ulama asal Minangkabau. Saado'eddin Djambek juga di kenal dengan datuk Sampono Radjo, Ia dilahirkan di Bukittinggi pada 29 Rabiul Awal 1329 H bertepatan pada tanggal 24 Maret 1911 M. Saadoe'ddin Djambek masuk dalam keluarga besar yang terpelajar, terhormat dan Islam. Ayahnya seorang ahli Falak bernama Syekh Muhammad Djambek dan kakeknya Muhammad Shaleh datuak Maleka, seorang kepala nagari Kurai. ${ }^{4}$

Menurut sejarah, Saadoe'ddin djambek pendidikan pertamanya di Hollands Inlandsche School (HIS) ${ }^{5}$ hingga tamat pada tahun 1924. Setelah itu ia melanjutkan studinya ke sekolah pendidikan guru, Holland Inlandsche Kweekschool

${ }^{4}$ Muhyiddin Khazin, "Ilmu Falak Dalam Teori Dan Praktik," Yogyakarta: Buana Pustaka, 2004, 49-80.

5 HIS ialah sekolah pada zaman penjajahan Belanda, setara dengan pendidikan sekolah dasar (SD), masa kini 
(HIK) di Bukittinggi. Setelah menamatikan HIK 1927, Saadoeddin Djambek melanjutkan pendidikan ke Hogere Kweekschool (HKS) dan menapatkan tahun $1930 .^{6}$

Dalam pendidikan Ilmu Falak, Saadoe'ddin Djambek banyak belajar dari ayahnya, karena ayahnya merupakan salah satu ahli Falak dimasanya. Karenanya tidak mengherankan pada usia yang sangat muda (18 tahun), ia sudah sangat tertarik pada Ilmu Falak, bahkan menjadi salah seorang ahli di bidang tersebut. Saadoeddin Djambek juga belajar secara mandiri dari buku Syaikh Djambek yang dikarang oleh Ahmad Badawi. Dengan latar belakang pendidikan Ilmu Falak yang telah dipelajarinya, pada tahun 1954-1955 Saadoe'ddin Djambek mencoba memperdalam pengetahuannya di fakultas Ilmu Pasti Alam dan Astronomi ITB. Dengan ilmu yang diperolehnya itu, Saadoe'ddin Djambek memadukan Ilmu Falak yang masih menggunakan metode klasik dengan ilmu astronomi yang sudah modern dengan menggunakan spherical trigonometry ( segitiga bola $)^{8}$

Dengan menggunakan teori-teori yang terdapat dalam spherical trigonometri Saadoe'ddin Djambek mencoba menyusun teori-teori untuk menghisab arah kiblat, menghisab terjadinya bayang-bayang kiblat, menghisab awal waktu salat dan menghisab awal bulan kamariah. Menurut Mustajib, karena sistem ini dikembangkan oleh Saadoe'ddin Djambek maka sistem ini juga dikenal dengan sistem hisab Saadoe'ddin Djambek. ${ }^{9}$

Praktik."

6 Khazin, "Ilmu Falak Dalam Teori Dan

7 Susiknan Azhari, Ilmu Falak: Perjumpaan Khazanah Islam Dan Sains Modern (Suara Muhammadiyah, 2007).

8 Azhari.

${ }^{9}$ Syamsul Anwar, Hari Raya, and Problematika Hisab Rukyat, "Hisab Bulan Kamariah: Tinjauan Syar'i Tentang Penetapan Awal Ramadan, Syawal Dan Zulhijah," Yogyakarta: Suara Muhammadiyah, 2008., 44.
Banyak buku yang telah dikaji oleh Saado'eddin Djambek, seperti Pati Kiraan karya Syekh Thaher Djalalu'ddin, Alamanak Djamilliah karya syekh Djambek, Hisab Hakiki karya K.H. Ahmad Badawi dan lainnya. Sistem perhitungan yang telah ia pelajari itu belum memuaskan dirinya dalam ilmu karena keakuratannya masih belum diuji. Ia terus mengasah dan memperdalam kemampuannya, dengan kursus Legere Akte ilmu pasti di Yogyakarta pada tahun 1941-1942 M, dan belajar di Fakultas Ilmu Fakultas Ilmu Pasti dan Ilmu Alam (FIPIA) Bandung pada tahun 1954-1955. ${ }^{10}$ Menurutnya teori itu dibangun untuk menjawab tantangan zaman. Artinya dengan meningkatkan kecerdasan umat di bidang ilmu pengetahuan maka teori-teori yang berkaitan dengan ilmu hisab perlu didialogkan dengan ilmu astronomi modern sehingga dapat dicapai hasil yang lebih akurat. Sistem yang dikembangkan oleh Saadoe'ddin Djambek relatif lebih mudah, karena bisa menggunakan kalkulator. ${ }^{11}$

Selain sebagai ahli Falak dan mengajar di IAIN Sunan Kalijaga Yogyakarta, Saadoe'ddin juga aktif dalam ORMAS Muhammadiah. Sehingga pada tahun 1969 ia diberi kepercayaan untuk menjadi ketua pimpinan pusat Muhammadiah pada Majelis Pendidikan dan Pengajaran di Jakarta periode 1969-1973. Selain itu Saadoe'ddin pernah diberi kepercayaan oleh Kementrian Agama untuk menjadi staf ahli menteri $\mathrm{P}$ dan $\mathrm{K}$. Sehingga ketika diadakan pertemuan pada tahun 1972 antara pakar hisab dan rukyat seIndonesia, sehingga terbentuknya Badan Hisab Rukyat yang ketuanya Saadoeddin Djambek. ${ }^{12}$

Seiring perjalanan hidupnya, pada tahun 1397 tepatnya 11 Zulhijjah $1379 \mathrm{H}$

10 Pengadilan Agama, Selayang Pandang Hisab Rukyat (Jakarta, 2004).

11 Saadoeddin Djambek, "Pedoman Waktu Shalat Sepanjang Masa," Jakarta: Bulan Bintang, 1974.

12 Susiknan Azhari, Pembaharuan Pemikiran Hisab Di Indonesia: Studi Atas Pemikiran Saadoe'ddin Djambek (Pustaka Pelajar, 2002)., 94. 
Saadoeddin Djambek meninggal di Jakarta. Makamnya dekat dengan makam Prof. T. M. Hasbi Ash-Shiddieqi. Sebagai ahli Falak, Saadoe'ddin pernah beberapa kali mewakili Indonesia dalam pertemuan internasional, di antaranya: tahun 1958 dalam kegiatan Konferensi Mathematica Education di Indonesia, tahun 1971 dilaksanakan di India System Comprebensive School di negara-negara India, Thailand, Swedia, Belgia, Inggris, Amerika Serikat, dan Jepang, dan tahun 1977 di Mekkah diadakan kegiatan survei mengembangkan Ilmu Falak dan rukyah dan kehidupan sosial di tanah suci Mekkah dan menghadiri First World Conference on Muslim Education $^{13}$

\section{PEMIKIRAN ILMU SAADOEDDIN DJAMBEK}

FALAK

Dalam penentapan awal waktu shalat Saadoeddin Djambek menjadikan data posisi matahari ketinggian atau jarak zenith hal yang pokok. Hal tersebut mengindikaskan bahwa penetapan awal waktu subuh sendiri tidak terlepas dari pengamatan terhadap fenomena matahari yang sering disebut dengan fajar. ${ }^{14}$

Wahbah Zuhaili menjelaskan bahwa yang dimaksud dengan fajar adalah awal permulaan tampaknya fajar membentang di ufuk timur seperti benang yang dibentangkan. $\mathrm{Hal}$ tersebut adalah permulaan cahaya matahari yang bersambung lagi tidak terputus. $^{15}$

Pada usia 40 tahun, Saadoe'ddin Djambek menekuni dunia tulis menulis. Hal ini terbukti dengan banyaknya karya-karya ilmiah yang ia hasilkan. Untuk lebih jelasnya dapat dilihat di tabel berikut ini:

\footnotetext{
13 Azhari.

14 Rizal Mubit, "Formulasi Waktu Salat Perspektif Fikih Dan Sains," Al-Marshad: Jurnal Astronomi Islam Dan Ilmu-Ilmu Berkaitan 3, no. 2 (2017).

15 Wahbah Al-Zuhayli and Abdul Hayyie AlKattani, Fiqib Islam Wa Adillatubu (Darul Fikir, 2010).
}

Waktu dan Djüdwal (penjelasan popular mengenai perjalanan Bumi, Bulan dan Matahari)

Karya pertama Saadoe'ddin Djambek ini menbahas mengenai konsep waktu secara komprehensif. Buku ini berjudul Wakti dan Djidwal perdaran benda langit Bumi, Bulan dan Matahari) merupakan karya yang terbit pada tahun 1952 M. Kajian dalam buku ini cukup variatif di mana terdapat penjelasan mengenai konsep gelap terang. Selain itu, terdapat pula penjelasan mengenai fase-fase. Bulan secara garis besar. ${ }^{16}$

Sebagaimana karya pertama Saadoe'ddin Djambek, karya ini diterbitkan pada tahun 1953 oleh Tintamas yang mana memiliki dua bahasan utama. Pembahasan pertama memaparkan tentang penanggalan masehi. Ketiga macam penanggalan ini disajikan dalam bentuk table yang disusun sedemikian rupa agar mudah dipahami. Selain itu, terdapat pula penjelasan untuk memahami setiap jenis penanggalan. ${ }^{17}$

Bagian kedua, membahas tentang jadwal kelima waktu salat. Saadoeddin Djambek tidak menyusun jadwalnya secara harian, namun ia menggunakan interpolasi empat hari $(1,5,9,13,17,21,25$, dan 29) pada setiap bulannya. Buku ini menyajikan pula cara pengunaan jadwal waktu salat serta koreksikoreksi waktu salat yang disesuaikan dengan lintang dan deklinasinya. Pada uraian terakhir, terdapat lampiran data lintang dan bujur kota se-Indonesia berpedoman pada Atlas BosNiermeyer yang disusun secara Alphabetical.

Arah Qiblat dan Tjara menghitungnja dengan Djalan Ilmu Ukur Segitiga Bola

Karya saadoeddin Djambek berikut ini membahas tentang arah kibla secara khusus. Terdapat empat sub bahasa, yaitu mengenai cara menentukan sebuat tempat, bola langit,

\footnotetext{
16 Djambek, "Pedoman Waktu Shalat Sepanjang Masa.”

17 Lihat Saadoeddin Djambek, Alamanak
} Djamijah, (Jakarta: Tintamas, 1952), 75. 
lingkaran imajiner Bumi serta perhitungan arah kiblat. Tiga sub bahasan awal dijelaskan untuk pengantar pembahasan perhitungan arah kiblat. Bab keempat tidak hanya menjajikan runmus perhitungan arah kiblat, tetapi juga penjelasan asal turunan dari rumus tersebut. Pembahasan astronomi cukup dominan, karena rumus-rumus yang ia gunakan dipengaruhi oleh analogi Napier. ${ }^{18}$

\section{Pedoman Waktu Shalat Sepanjang Masa}

Karya ini menampilkan materinya dalam bentuk table jadwal setiap waktu salat. Tulisan ini merupakan pedoman yang dapat digunakan untuk menentukan awal waktu salat pada setiap tanggal masehi bagi daerah yang terletak di antara $7^{0}$ utara dan $10^{\circ}$ lintang selatan. ${ }^{19}$ Buku ini terbagi menjadi dua bagian, pertama menyajikan table-tabel awal waktu shalat dan kedua berisi daftar nama kota disertai nilai lintang dan bujur serta koreksi dalam satuan menit agar jadwal tersebut sesuai. $^{20}$

\section{Shalat dan Puasa di Daerah Kutub}

Buku terbitan tahun $1974 \mathrm{M}$ ini hadir sebagai jawaban atas pertanyaan masyarakat muslim mengenai bagaimana menjalankan ibadah salat dan puasa apabila berada di daerah kutub. Secara georafis, letak daerah abnormal atau kutub termasuk kawsan beriklm ektrem, berbeda dengan kawasan normal yang memiliki jadwal waktu untuk ibadah secaera teratur. Kondisi di daerah kutub yang ekstrem mengakibatkan adakalanya waktu siang lebih pendek daripada waktu malam atau sebaliknya. Pendapat saadoeddin Djambek mengenai penentuan ibadah di daerah kutub yakni

\footnotetext{
18 Djambek, "Pedoman Waktu Shalat Sepanjang Masa.”

${ }^{19}$ Azhari, Pembaharuan Pemikiran Hisab Di
Indonesia.
20 Lihat skripsi Nila Suroya, Uji Akurasi

Pedoman Waktu Shalat Sepanjang Masa Karya Saadoeddin Djambek, Skripsi Sarjana, Semarang ; Fakultas Syari'ah dan Ekonomi Islam IAIN Walisongo Semarang
}

dengan mengqiyaskan seseorang seperti orang yang tidur atau pingsan. ${ }^{21}$

\section{Hisab Awal Bulan}

Karya ilmiah ini merupakan karya terakhir saadoeddin Djambek yang terbit pada tahun 1976 M. system perhitungan awal bulan kamariah saadoeddin Djambek diproses dengan menggunakan ilmu ukur segitiga bola (Spherical Trigonometry) yang diselesaikan dengan aturan logaritma ${ }^{22}$. Data yang digunaan dalam perhitungan pun yakni data astronomi barat dari amerika, almanac Nautika (Nautical Almanac). the nautical almanac ini disusun dengan kerja sama dengan Royal Greenwich observatory (inggris) dan United Stated Naval Observatory (Amerika). ${ }^{23}$ Demikianlah beberapa karya tulis Saadoe'ddin Djambek yang sempat terangkum dari berbagai referensi.

\section{BIOGRAFI TAHIR DJALALUDDIN}

Tahir Djaluddin al-Azhari nama panjangnya Syeikh Muhammad Thahir bin Muhammad bin Djaluddin Ahmad bin Abdullah al-Minangkabawi al-azhari.

Tahir Djaluddin lahir di Ampek Angkek Bukittinggi 7 November 1869 M bertepatan 4 Ramadhan 1286 H. Ayahnya bernama Sheikh Muhammad yang bergelar Tuanku Caking. Pada tahun 1881 Tahir Jalaluddin beliau menuntut ilmu ke Makkah sampai tahun 1893. Tahur jalaluddin mendalami ilmu agama diantaranya ilmu al Qur'an, ilmu Haditsh, ilmu Tauhid, ilmu Fiqah, ilmu Usul Fiqh, ilmu Nahu, ilmu Shorof, ilmu Bayan, ilmu Ma'ani, ilmu Badi',

\footnotetext{
${ }^{21}$ Lihat karya Saadoeddin Djambek, Shalat Dan Puasa Di Daerah Kutub, Jakarta ; bulan Bintang, 1974

22 Azhari, Pembaharuan Pemikiran Hisab Di Indonesia.

23 Muhammad Hadi Bashori, Pengantar Ilmu Falak: Pedoman Lengkap Tentang Teori Dan Praktik Hisab, Arah Kiblat, Waktu Salat, Awal Bulan Qamariah \& Gerhana (Pustaka Al Kautsar, 2015).
} 
'Arudh, ilmu Mantiq, ilmu Tafsir, ilmu Hisab dan Ilmu Falak ${ }^{24}$.

Selama di Makkah Syeikh Thahir banyak belajar dari Syeikh Ahmad Khatib. Setelah 12 tahun di makkah Syeikh Tahir pulang ke indonesia. ${ }^{25}$ adapun guru guru tahir Djalaluddin di Makkah pertama, Syeikh Muhammad Saleh al-Kurdi. Kedua Syeikh Abdul Haq, Tiga Syeikh Umar Syatha, Syeikh Muhammad al-Khaiyath dan Syeikh Ahmad Khatib al-Minankabawi. ${ }^{26}$

\section{KARYA ILMU DJALALUDDIN}

Adapun karya Syeikh Tahir Jalaluddin dalam bidang Ilmu Falak dapat dilihat sebagai berikut $:^{27}$

\begin{tabular}{|l|l|l|l|}
\hline No & Karya & Tahun & Tentang \\
\hline 1. & Natijatul Umur & $1355 \mathrm{H}$ & $\begin{array}{l}\text { Perkiraan } \\
\text { taqwm tarikh } \\
\text { hijiri dan } \\
\text { milady }\end{array}$ \\
\hline 2 & $\begin{array}{l}\text { Jadawil Pati } \\
\text { Kiraan }\end{array}$ & $\begin{array}{l}1356 \\
\mathrm{H}\end{array}$ & $\begin{array}{l}\text { Waktu yang } \\
\text { lima } \\
\text { Hala qiblat } \\
\text { dengan } \\
\text { logaritma }\end{array}$ \\
\hline 3 & $\begin{array}{l}\text { Nukbbatut } \\
\text { Taqrirat fi } \\
\text { Hisabil Auqat } \\
\text { wa Sammatil } \\
\text { Qiblat bil } \\
\text { Lugharitmat }\end{array}$ & $\mathrm{H}$ & $\begin{array}{l}\text { Kaedah } \\
\text { Ilmu Falak }\end{array}$ \\
\hline 4 & $\begin{array}{l}\text { Al-Qiblab fi } \\
\text { Nushushi } \\
\text { Ulamais }\end{array}$ & $\mathrm{H}$ & Ilmu Falak \\
\hline
\end{tabular}

${ }^{24}$ Faisal Ahmad Faisal Bin Abdul Hamid and Mohd Puaad Bin Abdul Malik, "Analisis Penulisan Syeikh Muhammad Tahir Jalaluddin Dalam Kitab Ta'yid Tadhkirah Muttabi'al-Sunnah.," Journal of Al-Tamaddun 12, no. 1 (2017).

25 Arwin Juli Rakhmadi Butar-Butar, "Kontribusi Syaikh Muhammad Thahir Jalaluddin Dalam Bidang Ilmu Falak," MIQOT: Jurnal Ilmu-Ilmu Keislaman 42, no. 2 (2019): 300-318.

${ }^{26}$ Mafri Amir, "Reformasi Islam Dunia Melayu Indonesia: Studi Pemikiran, Gerakan Dan Pengaruh Syeikh Muhammad Thair Jalal Al-Din,” 2004.

27 M. A. Arwin Juli Rakhmadi Butar-Butar, Mengenal Karya-Karya Ilmu Falak Nusantara; Transmisi, Anotasi, Biografi (LKIS PELANGI AKSARA, n.d.).

\begin{tabular}{|l|l|l|l|}
\hline Syafi'iyah fi ma & & \\
Yata'allaqu bi & & \\
Istiqbalil & & \\
Qiblatis & & \\
Syar'iyah & & \\
Manqulab min & & \\
Ummubat & & \\
Kutubil Marhab, & & \\
\hline
\end{tabular}

Dari table di atas, dapat diketahui bahwa karya Tahir Jalaluddin dalam bidang Ilmu Falak. Terkait dengan dengan waktu subuh terdapat pada kitab Pati Kiraan dan Nukbbatut Taqrirat fi Hisabil Auqat wa Sammatil Qiblat bil Lugharitmat.

Pemikiran Tahir Jalaluddin mengenai waktu shalat berisi tentang waktu yang lima dan logaritma hala kiblat. Kitab pati kiraan ini diselesaikan pada tahun $1356 \mathrm{H}$ tepatnya 20 Oktober di Kuala kangsarm Perak. Karya Tahir Jalaluddin dalam bentuk buku pertama kali dicetak oleh al-Ahmadayiah press Singapura tahun 1938 M. percetakan alAhmadiyah merupakan percetakan milik keluarga Raja Riau-Lingga di Singapura. Karya ini merupakan karya Falak yang memuat perhitungan waktu salat dan arah kiblat dan menggambarkan secara utuh pemikiran syeikh Tahir tentang hal itu. Kitab Pati Kiraan ini menggunakan dua bahasa yaitu bahasa melayu dan dituliskan dalam huruf jawi ${ }^{28}$

Pada bab awal, kitab Pati Kiraan berbahasa Arab. Namun ia mengalihkan bahasa kitabnya ke dalam bahasa melayu. Kemudan Syeikh Tahir juga menghaluskan bahasanya dengan menggunakan ahli bahasa melayu yang benama Zainal Abidin ibn Ahmad. Sebelum di terjemahkan, Syeikh Tahir Jalaluddin memberikan nama kitab ini yaitu

28 Tahir Jalaluddin, "Pati Kiraan Pada Menentukan Waktu Yang Lima Dan Hala Kiblat Dengan Logarithma," Kumpulan Tulisan Hisab Dan Falak Syeikh Mubammad Tabir Jalaluddin Al-Minankabawi AlAz̧bari, 1938. 
Nukhbatul al-Taqrirat fi Hisab al-awqat wa Sumut al-Qiblah bi al-Lugaritma ${ }^{29}$

Tahir Jalaluddin dalam penentuan waktu shalat pada tahap awal menentukan nilai fadl ad-dair. ini bertujuan untuk mencari jarak waktu zuhur dengan waktu shalat yang dhitung. ${ }^{30}$ fard ad-dair dalam astronomi disebut juga sudut waktu. Sudut sudut yang terbentuk dari lingkaran waktu dengan lingkaran meridian $^{31}$ pada berada pada kutub selatan dan kutub utara langit dibeti tanda $t$. Begitu juga pendapat Syekh Tahir Jalaluddin bahwa sudut waktu ini menujukkan rentang waktu kulminasi dari tempatnya matahari dari tempat kulminasi ke tempat kulminasi selanjutnya. Waktu berkulminasi itu dimaksud adalah waktu zuhur.

Sudut waktu ini dinamakan karena pada waktu itu setiap benda langit terletak pada lingkaran waktu yang sama.

Syeikh Tahir Jalaluddin dalam Kitab Pati kiraan juga menjelaskan mengenai mencari sudut waktu (fadl ad-dair) dengan mengambil nilai irtifa' matahari. Setelah itu ditambahkan dengan pencukup mail ${ }^{32}$, dan pencukup lintang. Hail penjumlahan antara pencukup mail dan pencukup lintang dinamakan "simpanan" yang selanjutnya dikurangi dengan pencukup mail. Hasil dari pengurangan tersebut dinamakan " lebih simpanan daripada pencukup mail”. Setelanjutnya hasil "simpanan" awal tadi dikurangi dengan pencukup lintang. Hasil dari pengurangan ini dinamakan 'lebih simpanan daripada pencukup lintang,33

\section{${ }^{29}$ Aziz, Syeikh Tahir Jalaluddin.}

30 Butar-Butar, "Kontribusi Syaikh Muhammad Thahir Jalaluddin Dalam Bidang Ilmu Falak."

Indonesia."

31 Amir, "Reformasi Islam Dunia Melayu

32 Butar-Butar, "Kontribusi Syaikh Muhammad Thahir Jalaluddin Dalam Bidang Ilmu Falak."

33 Amir, "Reformasi Islam Dunia Melayu Indonesia."
Menurut Syekh Tahir Jalaluddin dalam kitab Pati Kiraan, waktu waktu shalat dijelaskan sebagai berikut:

\begin{tabular}{|l|l|}
\hline Zuhur & $\begin{array}{l}\text { Sesuai jam Soekatan masa dengan jadwal } \\
\text { Syeikh Tahir Djalaluddin }\end{array}$ \\
\hline Asar & Sesuai gaya irtifa' pada hari yang dicari \\
\hline Magrib & $\begin{array}{l}\text { Jarak zm } 91^{0} \text { dengan } 1^{0} \text { sebagai koreksi } \\
\text { kerendahan ufuk dan setangah bulatan } \\
\text { matahari }\end{array}$ \\
\hline Isya' & Jarak zm $108^{0}$ dengan $1^{0}$ sebagai koreksi \\
\hline Subuh & Jarak zam $110^{0}$ dengan $1^{0}$ sebagai koreksi \\
\hline
\end{tabular}

Terkait waktu subuh, Tahir Jalaluddin berpendapat bahwa waktu subuh secara astronomi memiliki pertama, Lintang Tempat (Ф). Lintang adalah jarak dari suatu tempat ke khatulistiwa diukur dengan melalui meridian bumi. Dalam bahasa Arab dinamakan البلد dan biasanya ditandai dengan huruf Yunani $\Phi$ (phi, cara baca : fi). ${ }^{34}$

Kedua Bujur Tempat ( $\lambda$ ). Bujur tempat merupakan sudut antara bidang di meridian bidang tempat meridian yang dihitung dari Greenwich. bujur tempat dalam bahasa Arab dinamakan طول البلد yang dalam astronomi di lambang dengan huruf Yunani $\lambda$ (cara baca : lamda). ${ }^{35}$

Sebagaimana yang dikutip dari skripsi Muntoha yang berjudul Analisis Terhadap Toleransi Pengarub Perbedaan Lintang dan Bujur dalam Kesamaan Penentuan Awal Waktu Shalat, dijelaskan bahwa perbedaan bujur cukup besar pengaruhnya terhadap masuknya waktu shalat. $^{36}$

Selanjutnya, dalam waktu sholat juga terdapat zona waktu, bumi memiliki wilayah waktu yang disebut zona waktu. Zona waktu di bumi terdapat selisih $15^{0}$ yang bebatasan dengan meridian. Adapun batasan tengah

34 Muhammad Hidayat, "Penyebab Perbedaan Hasil Perhitungan Jadwal Waktu Salat Di Sumatera Utara," Al-Marshad: Jurnal Astronomi Islam Dan Ilmu-Ilmu Berkaitan 4, no. 2 (2018).

Fikih Dan Sains.”

35 Mubit, "Formulasi Waktu Salat Perspektif 36 Mubit. 
meridian menjadi pusatnya yaitu Greenwich.. pusat meridian tersebut membagi wilyah menjadi dua yaitu zona positif sebelah timur dan zona negarit wilyah barat. Antara zona tadi dibatasi oleh "Date Line" yang dibedakan dengan tanda -12 bagian Barat dan +12 bagian Timur.

Zoa waktu (date line) ini berpengaruh kepada setiap orang yang berada disekitarnya. Maka orang tersebut harus menyesuaikan hari sesuai dengan kalender pada hari tersebut. Adapun caranya menambah atau mengurangi dengan satuan hari (24). di bumi ini setiap negara harus menyesuaikan waktunya masingmasing contohnya GMT +7 WIB (Greenwich Mean Solar Time), maka $z=7$. Misalnya, Los Angeles memiliki $z=-8 .^{37}$

Indonesia sendiri terbagi kepada 3 zona waktu. Ini berdasarkan Keputusan Presiden RI Nomor 41 Tahun 1987 . Adapun pembagian zona waktu tersebut wilayah waktu Indonesia bagian Timur (+9), wilayah waktu Indonesia bagian Tengah (+8), dan wilayah waktu Indonesia bagian Barat (+7). Pembagian zona waktu tersebut diberi tanda masing masing oleh Badan Meteorologi Klimatologi dan Geofisika ${ }^{38}$

Selanjutnya, Ketinggian lokasi dari permukaan laut (h). Ketinggian lokasi ini dipergunakan dalam menentukan waktu terbit dan terbenamnya matahari. Secara georgrafis Matahari dapat dilihat lebih awal orang yang berada di dataran tinggi (gunung, bukit) dibandingkan orang yang berada di dataran rendah. ${ }^{39}$

37 Jalaluddin, "Pati Kiraan Pada Menentukan Waktu Yang Lima Dan Hala Kiblat Dengan Logarithma," 12.

38 Mubit, "Formulasi Waktu Salat Perspektif Fikih Dan Sains," 13.

${ }^{39}$ Mubit, 6.

\section{ANALISIS PEMIKIRAN TOKOH FALAK MINANGKABAU DAN KONTRIBUSINYA}

Dari penjelasan di atas dapat berikan gambaran bahwa. Saadoeddin Djambek dan Syeikh Tahir Jalaluddin merupakan salah satu ulama Falak yang banyak memberikan kontribusi dalam perkembangan Ilmu Falak di Indonesia, khusunya terhadap waktu shalat. Salah satu kitab karangan Syeihk Tahir Jalaluddin yang terkenal dengan waktu salat yaitu kitab pati kiraan, dimana dalam kitab ini Tahir Jalaluddin menentukan waktu shalat dengan memperhatikan 3 unsur yaitu: pertama, data data astronomi yang dipakai. Kedua tinggi matahari dan koreksinya. Ketiga penentuan lintang dan bujur tempat.

Selian itu waktu subuh menurut tahir jalaluddin meliputi: pertama, waqt al-Fadhilah (waktu utama), kedua, waqt al-ikhtiyar (waktu pilihan), tiga, waqt al-Jawaz (waktu relative), empat waqh al-karahah (waktu terlarang). ${ }^{40}$

Ketiga hal tersebut sangat penting dalam mementukan waktu shalat. Khusus terkait dengan ketinggian matahari dalam penentuan masuknya waktu shalat, syeikh tahir jalaluddin memberikan posisi atau ketinggian matahari dalam kitab pati kiraan. Terkhusus waktu ketinggian matahari pada waktu shalat isya' dan subuh yang menjadi polemic pada saat sekarang ini.

Menurut Syeikh Tahir Jalaluddin mengenai ketinggian matahari pada waktu isya adalah $108^{\circ}$. Hal ini dikarenakan bahwa, waktu isya menurut syeik tahir dimula dengan memudarnya cahaya merah (Syafaq al-Amhar) ada awan di bagian langit sebalah barat. Pertistiwa ini dikenal sebagai akhir senja astronomi (Astronomi Twilight). Keadaan demikian terjadi, bila titik pusat matahari berkedudukan $18^{\circ}$ di awah ufuk (horizon)

40 Butar-Butar, "Kontribusi Syaikh Muhammad Thahir Jalaluddin Dalam Bidang Ilmu Falak." 
sebelah barat atau bila jarak zenith matahari $=108^{0}$

Menurut Tahir Jalaluddin, waktu subuh dinilai dengan ketinggian $110^{\circ}$ yang dihitung dari zenith. Ketinggian matahari $110^{\circ}$ tersebut diartikan dengan $-20^{\circ}$ di bawah ufuk. Ini disebabkan matahari belum tampak dan masih berada di bawah ufuk timur yang bertepatan dengan kemunculan fajar sampai terbitnya matahari. Secara astronomi kondisi alam setelah waktu subuh terdapat bias cahaya partikel disebut cahaya fajar. namun cahaya fajar lebih kuat daripada cahaya senja sehingga pada posisi $-20^{\circ}$ di bawah ufuk timur, bintangbintang sudah mulai redup karena kuatnya cahaya fajar itu. ${ }^{41}$

Selanjutnya Syeikh Tahir dalam menentukan irtifa' ashar dengan menggunakan dil a'syar pencukup gayah al- irtifa' (nilai tan pencukupan gayah al-irtifa' merupakan tinggi maksimal matahari dari ufuk atau tepi langit pada hari yang dicari. Maka cara yang digunakan untuk mengatahui gayah al irtifa' yaitu apabila mail matahari dan lintang suatu tempat berlainan pihak (utara + selatan) sehingga di ambil selisih antara mail dan pencukup lintang.

Selanjutnya, pemikiran Saadoeddin Djambek erkait dengan waktu shalat. Pemikiran khususnya waktu ketinggian waktu subuh, saadoeddin djambek menetapkan ketinggian matahari pada posisi $-20^{\circ}$ yang terdapat pada buku jadwal waktu shalat yang pendapat itu di kutip dari gurunya yaitu Syeikh Tahir Jalaluddin pun yang mana saadoeddin Djambeun mengacu kepada kriteria hasil penelitian ibu yunus abad ke 10 di mesir. Ibnu yunus pada abad ke 10 tersebut memberikan kriteria waktu subuh pada posisi matahari $-20^{\circ}$ dikarenakan bahwa kondisi langit bersih dari cahaya polusi cahaya

41 M. A. Arwin Juli Rakhmadi Butar-Butar, Fajar \& Syafak; Dalam Kesarjanaan Astronom Muslim Dan Ulama Nusantara (LKIS PELANGI AKSARA, n.d.).
Hal yang sama disampaikan oleh saadoeddin djambek menyatakan bahwa pemikirannya cenderung memadukan penafsiran para ulama dengan teori teori astronomi dalam memahami nas-nas yang berkaitan dengan ketentuan-ketentuan awal waktu shalat. Saadoeddin djambek juga mengqiyaskan keadaan dan kondisi alam pada waktu itu.

Selain itu, juga di temukan dalam kitab kitab terdahulu terkait dengan waktu subuh yaitu Al-Marrakusyi, yang terdapat dalam kitab Jami' al-Mabady Wa al-Ghayat fi ilm al-Miqat.

Bahwa waktu subuh yang di tandai dengan Fajar Shadiq yang menjadi fajar kedua. Dalam kitab saadoeddin djambek di terangkan mengenai fajar shadiq ditandai dengan bentuk dan warna fajar. Secara fisis fajar shadiq merupakan cahaya yang memanjang ufuk, hal tersebut dikarenakan cahaya tersebut merupakan hasil hamburan dari atmosfer bumi. Berbeda dengan cahaya fajar kazib yang menjulang tinggi di karenakan oleh hamburan sebelum fajar shadiq yang mengecoh umat Islam dalam hal waktu subuh. Cahaya fajar shadiq selanjutnya akan semakin menguning ketika matahari semakin mendekati ufuk maka warna yang terlihat adalah warna merah yang dengan jelas akan menerangi benda-benda di sekitar kita, oleh karena itu disebutkan dengan fajar sipil. Namun secara ringkat akan di jelaskan bagaimana proses perubahan warna fajar antara lain: ${ }^{42}$

\section{Warna Putib Membentang}

Hal ini sebagaimana yang telah di jelaskan dalam surat al-Baqarah 187. Benang putih yang dimaksud adalah seperti halnya kondisi dimana bisa dilihat atau dibedakan warna putih dan hitam gelang yang dipakai di pergelangan kaki. Kondisi tersebut menunjukan matahari sudah mulai naik ke atas

42 Mughits, "Problematika Jadwal Waktu Salat Subuh Di Indonesia." 
ufuk, kemudian terlihat cahayanya di atas ufuk yang kemudian menyebar membentang di ufuk langit.

\section{Merab Membentang Putih Kekuning-Kuningan} Atau Kemerah Meraban Membentang)

Dalam hadis yang di riwayatkan ahmad, di sampaikan bahwa "bukan fajar itu cabaya yang meninggi di ufuk, akan tetapi yang membentang berwarna merah (fajar putib kemerah merahan)" H.R. Ahmad

Bentuk Fajar Shadiq warna putih kemerahan yang muncul dengan bentuk membentang di ufuk timur bisa dijadikan pertanda bahwa shalat subuh sudah sah dilakukan, sebagaimana yang dijelaskan oleh Slamet Hambali, MSi. Sebagaimana di kutip dari hadis aisyah disebutkan "bahwa saat para perempuan mukmin pulang dari shalat subuh berjamaah bersama Nabi SAW, mereka tidak dikenali karena masih gelap. Jadi fajar shadiq bukanlah fajar sipil karena saat fajar sipil sudah cukup terang. Juga bukan fajar nautika karena setelah shalat pun masih gelap, kalau demikian fajar shadiq adalah fajar astronomi, saat akhir malam $^{43}$

Secara teoritis, sesuai dengan pengertian fajar shadiq yang tercantum dalam Alquran yang diisyaratkan dengan penyataaan" terang bagimu benang putih dari benang hitam". Sesuai dengan asbabun nuzul ayat tersebut yang menyatakan bahwa pada zaman nabi beberapa orang laki-laki mengingatkan pada kedua kakinya benang putih dan benang hitam. Mereka terus makan dan minum sampai terlihat perbedaan diantara keduanya. Maka allah menurunkan kelanjutan "berupa fajar" sehingga mereka tahu bahwa yang dimaksud ialah malam dan siang. Dari sini, apabila dihubungkan dengan fajar dalam perspektif astronomi, maka pada batasan kurva cahaya fajar astronomilah yang seduai dengan kondisi tersebut. Karena ketika ketinggian matahari

43 Lihat T. Djamaluddin yang berjudul, “ twilight menurut astronomi” h. 2 mencapai $-18^{0}$ sampai $-13^{0}$ baru dibedakan warna antara hitam dan putih tersebut.

Berawal dengan kondisi tersebut, matahari akan semakin mendekati ufuk, sehingga cahaya di ufuk pun akan semakin banyak dan mampu menyinari beberapa benda yang ada di sekitar kita dan kondisi inilah yang disebut dengan fajar sipil yang kemudian disusul dengan sebutan fajar nautika. Pada intinya fajar shadiq merupakan cahaya fajar yang merupakan hasil dari hamburan cahaya matahari oleh partikel partikel di udara yang melingkupi bumi. ${ }^{44}$ Bentuk cahaya tersebut yakni membentang di sepanjang ufuk timur, dan walaupun itu hanya sedikit yang terbit maka kondisi tersebut sudah disebut dengan muculnya fajar shadiq. Jadi, yang menjadi patokan adalah bukan gelap atau tidaknya keadaan di sekeliling kita, akan tetapi cahaya membentang yang ada di ufuk bagian timur.

Secara tidak lansung, beberapa tempat yang berada di sebalah utara ataupun selatan equator bumi, maka posisi lingkaran pergeseran harian matahari akan lebih condong terhadap tegak lurus. Makin ke utara maupun makin ke selatan, maka posisinya akan lebih condong terhadap lingkaran pergeseran harian matahari tersebut. Konsekuensinya adalah matahari membutuhkan waktu yang lebih panjang untuk pada sebuah titik dari kriteria ketinggian matahari dari waktu shalat. Sehinga fajar pada sebuah tempat yang lebih ke utara ke selatan equator akan semakin panjang. Itu lah salah satu faktor bahwa penentuan ketinggian matahari pada posisi subuh -20 yang disampaikan oleh saadoeddin Djambek yang merujuk pada gurunya yaitu tahir jalaluddin yaitu $-19^{0}$ di daerah Mesir yang di tambah oleh Saadoeddin Djambek di Indonesia menjadi $-20^{\circ}$ dan sampai saat sekarang ini masih di pergunakan dan menjadi rujukan

${ }^{44}$ Muhammad Thahir Jalaluddin al-Mingkabau, Nukhbah al-Taqrirat fi Hisab al-Auqat wa Samt alQiblah bi al-Lugharitmat (t.t.:t.p., 1356/ 1937), h. 12 


\section{KESIMPULAN}

Perkembangan Ilmu Falak dari zaman dulu sampai sekarang semakin berkembang, perkembangan itu di pengaruhi oleh semakin banyaknya hasil pemikiran ulama yang mengkajinya. Di Indonesia perkembangan Ilmu Falak salah satunya di kembangkan oleh tokoh Falak asal Minangkabau yaitu Saadoeddin Djambek dan Tahir Jalaluddin. Pemikiran dua ulama Falak kelahiran Minangkabau tersebut sejak dahulu sampai sekarang masih eksis. Salah satu pemikiran yang masih di gunakan adalah terkait dengan waktu shalat, khususnya waktu shalat subuh. Tokoh Falak ini memberikan ketinggian matahari pada waktu subuh adalah $-20^{\circ}$. tokoh Falak minangkabau ini memberikan pendapat mengenai ketinggian waktu subuh $-20^{\circ}$ adalah di temukan dalam kitab Pati Kiraan karangan Tahir Jalaluddin yang pendapat tersebut di kembangkan oleh muridnya Saadoeddin Djambek dan sampai sekarang pemkiran mereka masih di gunakan untuk penentuan waktu subuh dan itulah yang lagi di teliti kembali oleh para pakar imu Falak di Indonesia sekarang ini. Salah satu alasan mereka mengemukakan dikarenakan bahwa Indonesia merupakan neraga yang terletak di daerah equator sehingga kenampakan fajar dapat di pengaruhi. Kedua bahwa, saadoeddin djambek dalam kitabnya pun menyebutkan bahwa posisi matahari pada waktu subuh itu $20^{\circ}$ itu hasil penambahan $-1^{0}$ yang pada awalnya $-19^{0}$ menjadi rujukan di deerah mesir. Sehingga di Indonesia menjadi $-20^{\circ}$.

Pendapat Syekh Tahir Jalaluddin didasarkan pada pendapat gurunya yang bernama Muhammad abi Al-Fadl. Beliau adalah sorang ahli astronomi Mesir. Sehingga jika di telusuri lebih jauh bahwa jaringan ulama Falak setelah Tahir Jalaluddin ada Syeikh Jamil Jambek ada juga Saadoeddin Djambek. yang mana keduanya merupakan tokoh Falak Minangkabau. Dengan demikian menurut penulis perkembangan Ilmu Falak di Indonesia sejak lahir sampai sekarang itu dilakukan oleh ulama yang berasal dari Minangkabau diantaranya Syeikh Tahir Jalaluddin, Djamil Jambek dan ada Saadoeddin Jambek. 


\section{DAFTAR KEPUSTAKAAN}

Agama, Pengadilan. Selayang Pandang Hisab Rukyat. Jakarta, 2004.

Akbar, Reza. "Sejarah Perkembangan Ilmu Falak Dalam Peradaban India Dan Keterkaitannya Dengan Islam.” Jurnal Ilmiah Islam Futura 17 (2017): 50-72.

Al-Zuhayli, Wahbah, and Abdul Hayyie Al-Kattani. Fiqib Islam Wa Adillatubu. Darul Fikir, 2010.

Amir, Mafri. "Reformasi Islam Dunia Melayu Indonesia: Studi Pemikiran, Gerakan Dan Pengaruh Syeikh Muhammad Thair Jalal Al-Din,” 2004.

Anwar, Syamsul, Hari Raya, and Problematika Hisab Rukyat. "Hisab Bulan Kamariah: Tinjauan Syar'i Tentang Penetapan Awal Ramadan, Syawal Dan Zulhijah." Yogyakarta: Suara Mubammadiyah, 2008.

Arwin Juli Rakhmadi Butar-Butar, M. A. Fajar \& Syafak; Dalam Kesarjanaan Astronom Muslim Dan Ulama Nusantara. Lkis Pelangi Aksara, n.d.

-. Mengenal Karya-Karya Ilmu Falak Nusantara; Transmisi, Anotasi, Biografi. Lkis Pelangi Aksara, n.d.

Azhari, Susiknan. Ilmu Falak: Perjumpaan Khazanah Islam Dan Sains Modern. Suara Muhammadiyah, 2007.

—. Pembaharuan Pemikiran Hisab Di Indonesia: Studi Atas Pemikiran Saadoe'ddin Djambek. Pustaka Pelajar, 2002.

Aziz, Sohaimi Abdul. Syeikh Tahir Jalaluddin: Pemikir Islam. Vol. 3. Khairur Rahim Ahmad Hilme, 2003.

Bashori, Muhammad Hadi. Pengantar Ilmu Falak: Pedoman Lengkap Tentang Teori Dan Praktik Hisab, Arah Kiblat, Waktu Salat, Awal Bulan Qamariah \& Gerhana. Pustaka Al Kautsar, 2015.

Butar-Butar, Arwin Juli Rakhmadi. "Kontribusi Syaikh Muhammad Thahir Jalaluddin Dalam Bidang Ilmu Falak." MIQOT: Jurnal Ilmu-Ilmu Keislaman 42, no. 2 (2019): 300-318.

Djambek, Saadoeddin. "Pedoman Waktu Shalat Sepanjang Masa." Jakarta: Bulan Bintang, 1974.

Hamid, Faisal Ahmad Faisal Bin Abdul, and Mohd Puaad Bin Abdul Malik. "Analisis Penulisan Syeikh Muhammad Tahir Jalaluddin Dalam Kitab Ta'yid Tadhkirah Muttabi’al-Sunnah.” Journal of Al-Tamaddun 12, no. 1 (2017).

Hidayat, Muhammad. "Penyebab Perbedaan Hasil Perhitungan Jadwal Waktu Salat Di Sumatera Utara." Al-Marshad: Jurnal Astronomi Islam Dan Ilmu-Ilmu Berkaitan 4, no. 2 (2018).

Jalaluddin, Tahir. "Pati Kiraan Pada Menentukan Waktu Yang Lima Dan Hala Kiblat Dengan Logarithma." Kumpulan Tulisan Hisab Dan Falak Syeikh Mubammad Tabir Jalaluddin AlMinankabawi Al-Azhari, 1938.

Khazin, Muhyiddin. "Ilmu Falak Dalam Teori Dan Praktik." Yogyakarta: Buana Pustaka, 2004, 49_ 80.

Mubit, Rizal. "Formulasi Waktu Salat Perspektif Fikih Dan Sains." Al-Marshad: Jurnal Astronomi Islam Dan Ilmu-Imu Berkaitan 3, no. 2 (2017).

Mughits, Abdul. "Problematika Jadwal Waktu Salat Subuh Di Indonesia." - 48, no. 2 (2014): 467487.

Rezi, Muhamad. "Pemahaman Hadis-Hadis Rukyat Hilal Dan Relasinya Dengan Realita Isbât Ramadhan Di Indonesia." Alhurriyah: Jurnal Hukum Islam 1, no. 1 (June 10, 2016): 109-24. https://doi.org/10.30983/ALHURRIYAH.V1I1.484. 